\title{
Research Article \\ Comparative study on technical efficiency of mechanized and traditional rice farm in Nepal
}

\author{
Prakash Acharya ${ }^{1 *}$, Punya Prasad Regmi ${ }^{2}$, Devendra Gauchan ${ }^{3}$, Dilli Bahadur $\mathrm{KC}^{4}$ and \\ Gopal Bahadur $\mathrm{KC}^{1}$ \\ ${ }^{1}$ Institute of Agriculture and Animal Sciences (IAAS), TU, Nepal \\ ${ }^{2}$ Agriculture and Forestry University (AFU), Rampur, Chitwan, Nepal \\ ${ }^{3}$ Alliance of Bioversity International and CIAT, Kathmandu, Nepal \\ ${ }^{4}$ CIMMYT Nepal Office, Lalitpur, Nepal \\ * Correspondence: acharyap2020@gmail.com \\ ORCID: https://orcid.org/0000-0002-2129-0495
}

Received: July 25, 2020; Accepted: October 15, 2020; Published: October 30, 2020

(C) Copyright: Acharya et. al (2020).

(c) (1) (9)

This work is licensed under a Creative Commons Attribution-Non Commercial 4.0

International License.

\begin{abstract}
The study was conducted among 274 mechanized and 220 traditional rice farms using multistage sampling technique to assess the technical efficiency in rice production among mechanized and traditional farmers in Jhapa, Sunsari and Bardiya districts. The Cobb-Douglas functional form of the stochastic production frontier was employed to obtain the technical efficiency in mechanized and traditional rice farms. The overall technical efficiency of the mechanized and traditional rice farm ranged from 40.31 to 92.23 and 31.21 to $85.02 \%$ t with the mean technical efficiency of 80.56 and $70.11 \%$ respectively. The scope of increasing output by adopting the technology adopted by the best performer was $19.44 \%$ in mechanized and $29.89 \%$ in traditional rice farm respectively. Majority of the farmers were operating at an efficiency level 70-80\% and 60-70\% in mechanized and traditional farms respectively. The average technical efficiency of mechanized rice farm was higher than that of traditional rice farm and the difference was significant. There was scope of increasing output through rational use of existing resources in both farm categories. Manures, chemical fertilizers had significant and positive effect to total yield of rice $\mathrm{kg} / \mathrm{ha}$. The effect of machine use to total yield of rice was positive and significant. Rice farms adopting machines were more technically efficient compared to traditional rice farm.
\end{abstract}

Keywords: Cobb-Douglas, Elasticity, Mechanization, Rice, Technical efficiency

Correct citation: Acharya, P., Regmi, P.P, Gauchan, D., KC, D.B. \& KC, G.B. (2020). Comparative study on technical efficiency of mechanized and traditional rice farm in Nepal. Journal of Agriculture and Natural Resources, 3(2), 82-91.

DOI: https://doi.org/10.3126/janr.v3i2.32484

\section{INTRODUCTION}

Agriculture is the main stay of Nepali economy contributing 26.98\% to country's Gross Domestic Product (GDP) (MoALD, 2019) and engage 60.4\% of its labor force (NPC, 2020). Food security is the burning issue in Nepal with more than two-thirds of the districts facing food shortages every year (Joshi et al., 2012). Rice is placed at the first rank among cereal crops in terms of area and production, contribution to GDP and AGDP and livelihood of the people (Regmi, 2017). Rice contributes about 20\% and 7\% to AGDP and GDP respectively and also supplies about $40 \%$ of the food calorie intake in Nepal (CDD, 2015). Currently, 
Journal of Agriculture and Natural Resources (2020) 3(2): 82-91

ISSN: 2661-6270 (Print), ISSN: 2661-6289 (Online)

DOI: https://doi.org/10.3126/janr.v3i2.32484

from the area of 1.49 million hectares of land, 5.61 million metric tons rice is produced in Nepal and the Terai region of the country shares more than $70 \%$ in term of area and production in Nepal (MoALD, 2019). However, the trend of importing rice (Milled and grain) has increased from 487 thousand metric ton to 769,000 metric tons in terms of quantity while the value has almost doubled from NRs.16 billion to NRs.32 billion in the last 6 years (DoC, 2019). Thus, this situation clearly demands the calls for improving yield of rice to ensure food and nutritional security in Nepal.

Adoption of improved technology and focus on agriculture research is one of the best options to increase agricultural production and productivity (Asfaw \& Bekele, 2010). Government of Nepal (GoN), Nepal Agricultural Research Council (NARC) has been playing a significant role to improve the rice productivity in the country. The current production is not sufficient to meet the demand of growing population and ensure food security in the country (Shrestha et al., 2020a; Shrestha et al., 2020b). However, the results have not been achieved satisfactory. The average growth rate in area and production of rice is only about $0.35 \%$ and $1 \%$ per year (Regmi 2017). Rice is labor intensive crop and thus requires large number of labors during various farm operations (Bhandari et al. 2015 \& Dhital, 2017). The rice productivity is greatly affected by labor scarcity during crop establishment (Liu et al, 2017). For the successful crop production, the timeliness of farm operations is important and use of improved implements and machineries is important for undertaking the farm operation in time. In this context, farm mechanization can help address shortage of labor, ease drudgery, enhance productivity and the timeliness of agricultural activities, promote efficiency in resource use (ESCAP, 2018).

Mechanization is important option to ensure profitability in agriculture (Vortia et al., 2019). According to Asefa (2012), if existing inputs and technologies are not efficiently utilized, trying to introduce new technologies will not be cost-effective. Thus, a technical-efficiency analysis is crucial to find out if farmers are efficient in the use of the existing resources and to decide when to introduce new technologies in mechanized and traditional rice farms. The role of mechanization in enhancing the efficiency in production system has still remained to be analyzed in Nepal. There have been several studies on exploring the production efficiency of rice in Nepal but study on farm mechanization impact on rice production efficiency has not been conducted till date. Thus, the present study examines the technical efficiency in mechanized farm and compares it with traditional rice farm so that farmers can be motivated to adopt new technologies. The study is also required to understand how the resources have been used and what are their contribution to output. The study also explores the efficiency distribution at which farmers in both the mechanized and traditional rice farm are supposed to fall.

\section{MATERIALS AND METHODS}

\section{Study area}

The study was conducted in Jhapa, Sunsari and Bardiya districts of Nepal. Jhapa and Sunsari districts were two Terai districts of province no. 1 and Bardiya was one of the Tarai districts of Province No. 5. These three districts were among the most potential district in rice production in Nepal. The selected three districts share $12.6 \%$ and $14.1 \%$ to total national area and production in Nepal (MoALD, 2019). These districts were also the command areas of Rice Zone and Super Zone units of Prime Minister Agriculture Modernization Project 
Journal of Agriculture and Natural Resources (2020) 3(2): 82-91

ISSN: 2661-6270 (Print), ISSN: 2661-6289 (Online)

DOI: https://doi.org/10.3126/janr.v3i2.32484

(PMAMP) which is a government owned project being implemented to facilitate for industrialization of rice sector via promotion of mechanization as one of the strategic interventions. Within the selected districts, respondents from one local unit from Jhapa (Kachankawal Rural Municipality), two local units from Sunsari (Duhabi Municipality and Gadi Rural Municipality) and two local units from Bardiya (Rajapur Municipality and Geruwa Rural Municipality) were selected for taking data through structured and semistructured questionnaires.

\section{Sampling design}

Multistage random sampling technique was adopted for the selection of study area and sample respondents for collection of information required for the study. The rice growing farm was divided into two categories i.e. Mechanized and Traditional rice farms. Mechanized farm referred to the rice farm that uses at least one or more of agricultural machines for at least one or more farm operations in tillage, transplanting, harvesting, threshing. Traditional farms were referred as rice farm that used none of the agricultural machines for rice cultivation. The rice grower of selected rural municipalities and municipalities were considered to be in sampling frame. The data was collected through structured and semistructured questionnaires. Based on the population size, the sample size of the study was 494 respondents which constituted 220 respondents from traditional and 274 respondents from mechanized rice farms. The focused group discussion, key informant interview, stakeholders analysis were performed during study. The sample size was determined using the following formula and was also verified by using Raosoft software for determination of sample size.

Table 1: Sampling frame

\begin{tabular}{lcccc}
\hline \multirow{2}{*}{ District } & \multicolumn{2}{c}{ Population size (No.) } & \multicolumn{2}{c}{ Sample size (No.) } \\
\cline { 2 - 5 } & Mechanized & Traditional & 91 & Traditional \\
\hline Jhapa & 1895 & 334 & 91 & 69 \\
Sunsari & 1760 & 240 & 92 & 76 \\
Bardiya & 2007 & 354 & 274 & 220 \\
Total & 5662 & 928 & Total Sample size: 494 \\
\hline \multicolumn{5}{c}{}
\end{tabular}

The sample size was determined using the following formula:

$$
\mathrm{n}=\left[\frac{\left[N \mathrm{z}^{2} \mathrm{p}(1-\mathrm{p})\right]}{\left[(\mathrm{N}-1) \mathrm{d}^{2}+\mathrm{z}^{2} \mathrm{p}(1-\mathrm{p})\right]}\right]
$$

(Daniel \& Cross, 2013)

Where:

$$
\begin{aligned}
& n=\text { Sample size } \\
& N=\text { Total population size/household } \\
& p=\text { Estimated proportion of population included }(50 \%) \\
& d=\text { Error limit }(10 \%)
\end{aligned}
$$

The field survey was conducted in the month of December 15, 2018 - April15,2019.

\section{Analytical methods}

The technical efficiency was calculated by adopting Input-Oriented Measures. In order to estimate the technical efficiency of mechanized and traditional rice farms in study area, stochastic production frontier was used. The data was analyzed using STATA software. The 
Journal of Agriculture and Natural Resources (2020) 3(2): 82-91

ISSN: 2661-6270 (Print), ISSN: 2661-6289 (Online)

DOI: https://doi.org/10.3126/janr.v3i2.32484

Cobb-Douglas functional form of the stochastic production frontier was employed to estimate the technical efficiency in the study area. The Cobb-Douglas stochastic frontier production model is specified in its explicit form as:

$$
Y i j=a X i j_{1}{ }^{\beta_{1}} X_{i_{2}}{ }^{\beta_{2}} X_{i j_{3}}{ }^{\beta_{3}} X_{i j_{4}}^{\beta_{4}} \mathrm{Xij}_{5}{ }^{\beta_{5}} \mathrm{Xij}_{6}{ }^{\beta_{6}}
$$

(Mohammed 2012; Danso-Abbeam et al., 2012)

The Cobb-Douglas stochastic frontier production model is specified in its explicit form as:

$\operatorname{Ln} Y_{i j}=\beta 0+\beta_{1} X i_{1}+\beta_{2} X i_{2}+\beta_{3} X i_{3}+\beta_{4} X i_{4}+\beta_{5} X i_{5}+\beta_{6} X i j_{6}+v i+u i$.

Where, $\mathrm{Ln}=$ Natural logarithm

$Y_{i j}=$ Output $(\mathrm{kg})$ of $i^{\text {th }}$ crop on $j^{\text {th }}$ type of farm

$X_{i j 1}=$ Human labor (man days) for $i^{\text {th }}$ crop on $j^{\text {th }}$ type of farm

$\mathrm{X}_{\mathrm{ij} 2}=$ Seed $(\mathrm{kg})$ for $\mathrm{i}^{\text {th }}$ crop on $\mathrm{j}^{\text {th }}$ type of farm

$\mathrm{X}_{\mathrm{ij} 3}=$ Machine hours (hours) for $\mathrm{i}^{\text {th }}$ crop on $\mathrm{j}^{\text {th }}$ type of farm

$X_{\mathrm{ij} 4}=$ Manures and fertilizers use $(\mathrm{kg} / \mathrm{ha}) i^{\text {th }}$ crop on $j^{\text {th }}$ type of farm

$X_{i j}=$ Chemical Fertilizers $(\mathrm{kg})$ for $i^{\text {th }}$ crop on $j^{\text {th }}$ type of farm

$\mathrm{X}_{\mathrm{ij6}}=$ Agro Chemical (litre/ha) for $\mathrm{i}^{\text {th }}$ crop on $\mathrm{j}^{\text {th }}$ type of farm

$\mathrm{X}_{\mathrm{ij} 7}=$ Irrigation (hours/ha)

$\mathrm{Vi}=$ Error term measuring errors not under the control of farmers

$\mathrm{Ui}=$ Error term measuring errors under the control of farmers.

$\beta_{1,} \beta_{2 \ldots \ldots \ldots . . .}=$ Coefficients to be estimated

\section{RESULTS AND DISCUSSION}

\section{Estimation of technical efficiency in mechanized rice farm}

The technical efficiency was calculated by adopting Input-Oriented Measures. In this frontier model the yield $(\mathrm{kg} / \mathrm{ha})$ was dependent variable for both types of farm. The maximum possible independent variables influencing the dependent variables were explored and fit into the model. The independent variables identified were machine hours (hours/ha), seed rate $(\mathrm{kg} / \mathrm{ha})$, compost and manures ( $\mathrm{kg} / \mathrm{ha})$, chemical fertilizers $(\mathrm{kg} / \mathrm{ha})$, agro-chemical use (liter/ha), irrigation hours (hours/ha), bullock use (days/ha), human labor (man days/ha). To estimate the technical efficiencies of mechanized and traditional rice farms, natural log transformation was done for dependent and all the independent variables. The coefficients estimated for mechanized and traditional rice farms using stochastic production frontier is presented in the Table 2.

The estimated coefficient (-0.011) for human labor was negative and insignificant which means additional use of labor in mechanized rice farm does not increase the output anymore. This finding was in line Uldare (2014) with who found the estimated coefficient of labor was positive and non-significant for mechanized and non-mechanized rice farms in Nigeria. The estimated coefficient for seed was positive but insignificant. This means additional use of seed per hectare will not increase the output. This could be because farmers were already using the seed more than recommended rate so that additional seed per hectare would not contribute to the output increment significantly. Similarly, coefficients for compost/manures and chemical fertilizers was positive and significant at $5 \%$ and $1 \%$ level of significance. This means, increase in level of manures/compost and chemical fertilizers keeping other inputs constant would increase the level of output in mechanized rice farm. This result coincides 
Journal of Agriculture and Natural Resources (2020) 3(2): 82-91

ISSN: 2661-6270 (Print), ISSN: 2661-6289 (Online)

DOI: https://doi.org/10.3126/janr.v3i2.32484

with the findings of Oladiebo and Fajuyigbe (2007) who concluded the significant positive relation between level of fertilizers and output for upland rice cultivation in Osun state. The study revealed that the estimated coefficients for agro-chemicals used in mechanized rice farm was 0.908 and was significant at $5 \%$ level of significance depicting one percent increase in use of agro-chemicals would increase the output by 0.9 percent. This result is consistent with Canete and Temanel (2017) who found the use of chemicals to control disease pest and chemical fertilizers had significant positive effect to total yield. Coefficient (0.059) for machine use was positive and significant implying that increase in hours of machines use for rice cultivation would increase the output level significantly. Negative and significant coefficient (-0.04) for bullock use indicated that every percent increase in bullock use (in days) would decrease the rice output by 0.04 percent. The presence or absence of technical inefficiency was tested in the study using the important parameter of log likelihood i.e. $\lambda=$ $\sigma \mathrm{u} / \sigma \mathrm{v}$. If $\lambda=0$ there were no effects of technical inefficiency, and all deviations from the frontier were due to noise (Aigner et al. 1977). The estimated value of $\lambda$ was 1.231 significantly differed from zero. So, the null hypothesis that there is no inefficiency effect was rejected at the 0.1 percent level using the Z-statistic, suggesting the existence of inefficiency effects for rice farmers in mechanized rice farm category.

Table 2: Estimated Stochastic Frontier Production Function for mechanized rice farms

\begin{tabular}{|c|c|c|c|c|}
\hline Variables & Coefficients & Std. Error & $\mathrm{z}$, & Sig. $\mathrm{P}>\mathrm{Z}$ \\
\hline Log Seed (kg/ha) & 0.071 & 0.043 & 1.64 & 0.101 \\
\hline Log Compost and Manures (kg/ha) & $0.061 * *$ & 0.016 & 3.52 & 0.00 \\
\hline Log Chemical Fertilizer (Kg/ha) & $0.05 *$ & 0.025 & 1.97 & 0.049 \\
\hline Log Machine use (Hours/ha) & $0.059 *$ & 0.026 & 2.49 & 0.013 \\
\hline Log Human Labor (Man days/ha) & -0.011 & 0.024 & -0.37 & 0.708 \\
\hline Log Bullock Use (Days/ha) & $-0.04 *$ & 0.019 & -2.16 & 0.031 \\
\hline Log Agro-Chemicals Use (Liter/ha) & $0.908 * *$ & 0.019 & 9.96 & 0.00 \\
\hline Log Irrigation (Hour/ha) & -0.001 & 0.014 & -0.13 & 0.90 \\
\hline Constant & 6.433 & 0.349 & 18.56 & 0.00 \\
\hline Sigma v & 0.082 & 0.009 & & \\
\hline Sigma u & 0.101 & 0.022 & & \\
\hline Sigma 2 & 0.017 & 0.003 & & \\
\hline Lambda $(\lambda)=\delta \mathrm{u} / \delta \mathrm{v}$ & 1.231 & 0.031 & & \\
\hline \multicolumn{5}{|l|}{ Summary Statistics } \\
\hline Log Likelihood & & 238.13 & & \\
\hline Wald Chi 2 & & 185.88 & & \\
\hline Prob $>$ Chi 2 & & 0.00000 & & \\
\hline Mean Technical Efficiency & & 80.56 & & \\
\hline
\end{tabular}

Note: $*$ and $* *$ indicate significant at $5 \%$ and $1 \%$ level of significance respectively.

\section{Estimation of technical efficiency in traditional rice farm}

The estimated coefficients obtained from the Stochastic Frontier Production Function for traditional rice farm is presented in the Table 3.The estimated coefficient (0.273) for compost/manures was positive and significant at 5\% level of significance. This implied that increase in use of composts and manures by one percent would increase the output level by $0.27 \%$. There was significant effect of chemical fertilizer to the total output indicating that one percent increase in chemical fertilizers would increase the output by $0.015 \%$. The coefficient for human labor was positive and significant at 5\% level of significance which means increase in human labor (man days) by one percent will increase the output by 0.028 percent. Estimated coefficient (0.034) for bullock labor use in traditional farm was significant 
Journal of Agriculture and Natural Resources (2020) 3(2): 82-91

ISSN: 2661-6270 (Print), ISSN: 2661-6289 (Online)

DOI: https://doi.org/10.3126/janr.v3i2.32484

at 5\% level of significance. This showed that increase in bullock labor use would significantly contribute to output increment. The effect of seed use to the output was found to be negative and insignificant. This indicated that the additional use of seed for rice cultivation would not increase the output level significantly. This was because farmers of all category were using the seed in excess of recommended rate and thus increase in seed rate beyond the recommended rate would not increase the output. Similarly, the estimated coefficient for plant protection measures (agro-chemicals) was found to be positive and non-significant indicating that increase in agro chemicals as a plant protection measure would not significantly increase the output.

The presence or absence of technical inefficiency was tested in the study using the important parameter of $\log$ likelihood i.e. $\lambda=\sigma \mathrm{u} / \sigma \mathrm{v}$. If $\lambda=0$ there were no effects of technical inefficiency, and all deviations from the frontier were due to noise (Aigner et al. 1977). The estimated value of $\lambda$ was 1.176 significantly differed from zero. So, the null hypothesis that there is no inefficiency effect was rejected at the 0.1 percent level using the Z-statistic, suggesting the existence of inefficiency effects for rice farmers in traditional rice farm category.

Table 3: Estimated Stochastic Frontier Production Function for traditional rice farms

\begin{tabular}{|c|c|c|c|c|}
\hline Variables & Coefficients & Std. Error & $\mathrm{z}$, & Sig. $\mathrm{P}>\mathrm{z}$ \\
\hline Log Seed (kg/ha) & -0.010 & 0.007 & -1.48 & 0.138 \\
\hline Log Compost and Manures (kg/ha) & $0.273 * *$ & 0.003 & 83.81 & 0.00 \\
\hline Log Chemical Fertilizer (Kg/ha) & $0.013 *$ & 0.006 & 2.03 & 0.043 \\
\hline Log Human Labor (Man days/ha) & $0.028 *$ & 0.013 & 2.12 & 0.034 \\
\hline Log Bullock Use (Days/ha) & $0.034 * *$ & 0.01 & 3.37 & 0.001 \\
\hline Log Agro-Chemicals Use (Liter/ha) & 0.001 & 0.006 & 0.08 & 0.933 \\
\hline Log Irrigation (Hours/ha) & -0.002 & 0.006 & -0.82 & 0.41 \\
\hline Constant & $5.948 * *$ & 0.086 & 69.01 & 0.00 \\
\hline Sigma v & 0.017 & 0.0008 & & \\
\hline Sigma u & 0.020 & 0.01 & & \\
\hline Sigma 2 & 0.051 & 0.000 & & \\
\hline $\operatorname{Lambda}(\lambda)=\delta \mathrm{u} / \delta \mathrm{v}$ & 1.176 & 0.011 & & \\
\hline \multicolumn{5}{|l|}{ Summary statistics } \\
\hline Log likelihood & \multicolumn{4}{|c|}{583.36} \\
\hline Prob. $>\mathrm{Chi}^{2}$ & \multicolumn{4}{|c|}{0.000} \\
\hline Wald $\mathrm{Chi}^{2}$ & \multicolumn{4}{|c|}{9279.29} \\
\hline Mean Technical Efficiency & \multicolumn{4}{|c|}{70.11} \\
\hline
\end{tabular}

Note: $*$ and $* *$ indicate significant at $5 \%$ and $1 \%$ level of significance respectively.

\section{Frequency Distribution of mechanized rice farms based on technical efficiency}

Table 4 depicts efficiency categories of mechanized and traditional rice farm in the study area. The overall technical efficiency of the mechanized rice farm ranged from 40.31 to 92.23 with the mean technical efficiency of 80.56 percent. This indicates that famers of mechanized rice farms could lessen their input use on an average of $19.44 \%$ in order to operate at full efficiency level, Therefore, the study concluded that there is still possibility of increasing the rice yields by $19.44 \%$ adopting the technology adopted by the best performers. Similarly, the overall technical efficiency of the traditional rice farm ranged from 31.21 to 85.02 with the mean technical efficiency of 70.11 percent. This implies that the nonmechanized rice farm produces $70.11 \%$ of the maximum attainable output with given input 
Journal of Agriculture and Natural Resources (2020) 3(2): 82-91

ISSN: 2661-6270 (Print), ISSN: 2661-6289 (Online)

DOI: https://doi.org/10.3126/janr.v3i2.32484

levels. Wide gap between low and high technical efficiency was evident for both mechanized and traditional rice farm. This also mean that rice farmer could achieve the technical efficiency level of its most efficient counter parts. Kea (2016) also found the gaps in technical efficiency in rice production system with the mean technical efficiency of $78.4 \%$ indicating room to further improve the technical efficiency.

The mean technical efficiency in mechanized rice farm implies that on an average farm produces $80.56 \%$ of the maximum attainable output with given input levels. The average rice grower in mechanized rice farm could increase output by $12.65 \%$ approximately (180.56/92.23). Similarly, the most technically inefficient farmer could increase the production by $56.29 \%(1-40.31 / 92.23)$ if he/she could increase the level of technical efficiency to the most efficient counterpart. Since the mean technical efficiency of mechanized rice farm is $80.56 \%$, it can be concluded that the $19.44 \%$ of the output is lost due to the inefficiency in rice producing system.

Similarly, the mean technical efficiency in traditional rice farm implies that the average farm produces $70.11 \%$ of the maximum attainable output with given input levels. The average rice grower in traditional rice farm could increase output by $17.53 \%$ approximately (170.11/85.02). Similarly, the most technically inefficient farmer could increase the production by $63.29 \%(1-31.21 / 85.02)$ if he/she could increase the level of technical efficiency to the most efficient counterpart. Since the mean technical efficiency of traditional rice farm was $70.11 \%$, it can be concluded that the $29.89 \%$ of the output is lost due to the inefficiency in rice producing system.

Table 4: Range of technical efficiency of respondents under mechanized and traditional farm category

\begin{tabular}{cccc}
\hline \multirow{2}{*}{ Efficiency level } & & \multicolumn{2}{c}{ Farm Category } \\
\cline { 3 - 4 } & Total $(\mathrm{N}=494)$ & Mechanized $(\mathrm{N}=274)$ & Traditional $(\mathrm{N}=220)$ \\
$0.2-0.3$ & $00(00)$ & $00(00)$ & $00(00)$ \\
$0.3-0.4$ & $12(2.43)$ & $00(00)$ & $12(5.46)$ \\
$0.4-0.5$ & $29(5.87)$ & $11(4.01)$ & $18(8.18)$ \\
$0.5-0.6$ & $51(10.32)$ & $28(10.22)$ & $23(10.45)$ \\
$0.6-0.7$ & $136(27.53)$ & $48(17.52)$ & $88(40.0)$ \\
$0.7-0.8$ & $158(31.98)$ & $105(38.32)$ & $53(24.09)$ \\
$0.8-0.9$ & $87(17.61)$ & $70(25.55)$ & $17(7.73)$ \\
$0.9-1.0$ & $21(4.25)$ & $12(4.38)$ & $9(4.09)$ \\
\hline Total & $494(100) * *$ & $274(100)$ & $220(100)$ \\
\hline
\end{tabular}

Notes: $* *$ indicates significant at $1 \%$ significance level Pearson's Chi-square value $=91.53$, at $\mathrm{p}$-value $=0.01$. Figures in parentheses indicate percent.

In mechanized rice farm, majority of the farmers were operating at an efficiency level of 0.7 to 0.8 (i.e. $70 \%$ to $80 \%$ efficiency). About one-third farms were at efficiency level of 0.7-0.8 followed by one-fourth farms at 0.8-0.9 and remaining farms were operating below $70 \%$ of efficiency. Similarly, in traditional rice farm, majority of the farmers were operating at an efficiency level of 0.6 to 0.7 (i.e. $60 \%$ to $70 \%$ efficiency). About $40.0 \%$ farms were at efficiency level of 0.6 -0.7 followed by one fourth farms at 0.7-0.8 and remaining farms were operating below $60 \%$ of efficiency.

\section{t-test of technical efficiency of traditional and mechanized rice farms}


Journal of Agriculture and Natural Resources (2020) 3(2): 82-91

ISSN: 2661-6270 (Print), ISSN: 2661-6289 (Online)

DOI: https://doi.org/10.3126/janr.v3i2.32484

The estimated means of technical efficiency between mechanized and traditional rice farm was tested with t-test to find out whether the difference of means of technical efficiency were significant or not. The mean difference of the technical efficiency between mechanized and traditional rice farm was found to be 0.1045 . The average technical efficiency of mechanized rice farm (0.8056) was higher than that of traditional rice farm (0.7011) and the difference was statistically significant at $1 \%$ level of significant.

Table 5: Difference in efficiency level of mechanized and traditional rice farm

\begin{tabular}{lcccccc}
\hline Particular & \multicolumn{2}{c}{ Farm category } & \multirow{2}{\text{Mean}}{} & t-value & $\begin{array}{c}\text { p-value } \\
\text { (sig.) }\end{array}$ & df \\
\cline { 2 - 3 } $\begin{array}{l}\text { Technical } \\
\text { Efficiency }\end{array}$ & 0.8056 & 0.7011 & $0.1045 * *$ & 15.62 & 0.00 & 492 \\
\hline
\end{tabular}

Note: **indicates significant at $1 \%$ level of significance.

This was in line with Vortia (2019) who concluded that rice farms with higher level of mechanization are technically more efficient than the others although both farm groups are technically inefficient in rice production. The current study revealed that there was still scope of increasing output level of rice by increasing the efficiency of farm through wise mobilization and use of existing resources. The Pearson's Chi-square value was 91.53 and the difference in efficiency between mechanized and traditional rice farm was found statistically significant at $1 \%$ level.

\section{CONCLUSION}

The overall technical efficiency of the mechanized rice farm and traditional rice farm ranged from 40.31 to 92.23 and 31.21 to 85.02 percent with the mean technical efficiency of 80.56 and 70.11 respectively. This indicated that that famers of mechanized rice farms and traditional rice farm could increase the output by $19.44 \%$ and $29.89 \%$ in order to operate at full efficiency level respectively. Wide gap between low and high technical efficiency was evident of inefficiency for both mechanized and traditional rice farm. This also mean that rice farmer could achieve the technical efficiency level of its most efficient counter parts. In mechanized rice farm, majority of the farmers were operating at an efficiency level of 0.7 to 0.8 (i.e. $70 \%$ to $80 \%$ efficiency and in traditional rice farm, majority of the farmers were operating at an efficiency level of 0.6 to 0.7 (i.e. $60 \%$ to $70 \%$ efficiency). The overall efficiency level of both the farms suggest that increase in output and decrease in cost could be obtained using available technology. The elasticity of various input used for rice production in both the farm indicated that the manures, chemical fertilizers had significant and positive effect to total yield of rice $\mathrm{kg} / \mathrm{ha}$. The effect of bullock use (days) was positive and significant to total output $\mathrm{kg} / \mathrm{ha}$ whereas it had non-significant impact in mechanized rice farm. The effect of machine use to total yield of rice was positive and significant indicating additional use of machine hours would increase the output. There is scope of increasing the efficiency of rice production system through use of machines and inefficiency can be minimized by creating awareness, educating farmers, technical capacity buildup of farmers.

\section{Acknowledgement}

Authors are indebted to CIMMYT Nepal for providing partial financial support to undertake this research. The technical supports received from the officials of CIMMYT Nepal office are highly acknowledged. 
Journal of Agriculture and Natural Resources (2020) 3(2): 82-91

ISSN: 2661-6270 (Print), ISSN: 2661-6289 (Online)

DOI: https://doi.org/10.3126/janr.v3i2.32484

\section{Authors' contributions}

P. Acharya conducted research and wrote the paper. P.P. Regmi, D. Gauchan, D.B. KC and G.B. KC revised and finalized the paper.

\section{Conflict of interest}

The authors declare that there is no conflict of interest regarding publication of this manuscript.

\section{REFERENCES}

Aigner D.J, Lovell, C.A.K., \& Schmidt, P. (1977). Formulation and estimation of stochastic frontier production function models. Journal of Econometrics, 6(1), 21-37. DOI: https://doi.org/10.1016/0304-4076(77)90052-5.

Asefa S. (2012). Analysis of technical efficiency of crop producing smallholder farmers in Tigray, Ethiopia. 'Munich Personal RePEc Archive (MPRA). Retrieved from https://mpra.ub.uni-muenchen.de/40461/1/MPRA_paper_40461.pdf

Asfaw S., \& Shiferaw, B. (2010). Agricultural technology adoption and rural poverty: Application of an endogenous switching regression for selected east African countries. In: Proceedings of the conference at the joint 3rd African Association of Agricultural Economists (AAAE), 19-23.

Bhandari, N.B., Bhattarai, D., \& Aryal, M. (2015). Cost, production and price spread of cereal crops in Nepal: A time series analysis. MoAD, Lalitpur, Nepal, Pp.45-55.

Canete, D.C., \& Temanel, B.E. (2017). Factors influencing productivity and technical efficiency of rice farmers in Isabela, Philippines. Journal of Advanced Agricultural Technologies, 4(2), 111-122.DOI: https://doi.org/10.18178/joaat.4.2.111-122

CDD. (2015). Rice varietal mapping in Nepal: Implication for development and adoption. Crop Development Directorate, Department of Agriculture, Lalitpur, p.2.

Daniel, W.W. \& Cross, C.L. (2013). Biostatistics: A foundation for analysis in the health sciences. $10^{\text {th }}$ edition. New York: John Wiley \& Sons.pp 190. Retrieved from: http://docshare02.docshare.tips/files/22448/224486444.pdf

Danso-Abbeam, G., Aidoo, R., Agyemang, K.O., \& Ohene-Yankyera, K. (2012). Technical efficiency in Ghana's cocoa industry: Evidence from Bibiani- Anhwiaso-Bekwai District. Journal of Development and Agricultural Economics, 4(10), 287-294. DOI: https://doi.org/10.5897/JDAE12.052

Dhital, B. (2017). Economy of production and labor requirement in major field crops of Kavre, Nepal. Int. J. Environ. Agric. Biotechnology, 2, 350353. DOI: https://doi.org/10.22161/ijeab/2.1.43

DoC. (2019). Annual foreign trade statistics. Department of Customs, Nepal. Retrieved from https://archive.customs.gov.np/en/monthlystatstics.html.

ESCAP. (2018). Enabling sustainable food systems through mechanization solutions for production and processing. Economic and Social Commission for Asia and the Pacific Committee on Environment and Development, fifth session Bangkok, 21-23 November 2018, Note by the secretariat. retrieved from https://www.unescap.org/sites/default/files/CED5_INF1\%20\%28002\%29.pdf

Joshi, K.D., Conroy, C., \& Witcombe, J.R. (2012). Agriculture, seed, and innovation in Nepal: Industry and policy issues for the future. International Food Policy Research Institute, p.13.

Kea, S., Li, H., \& Pich, L. (2016). Technical efficiency and its determinants of rice production in Cambodia. Economics, 4(22), 117.DOI: https://doi.org/10.3390/economies4040022 
Journal of Agriculture and Natural Resources (2020) 3(2): 82-91

ISSN: 2661-6270 (Print), ISSN: 2661-6289 (Online)

DOI: https://doi.org/10.3126/janr.v3i2.32484

Liu, Q., Zhou, X., Li, J., \& Xin C. (2017). Effects of seedling age and cultivation density on agronomic characteristics and grain yield of mechanically transplanted rice. Sci. Rep. 7, 1-10. DOI: https://doi.org/10.1038/s41598-017-14672-7

MoALD. (2019). Statistical information on Nepalese agriculture 2017/18. Press release on estimation of paddy crop production for the fiscal year 2018/19 by MoALD on December 29, 2019.

Mohammed, W.A. (2012). Technical efficiency of sorghum production in the Hong local government area of Adamawa State, Nigeria. Russian Journal of Agricultural and Socio-economic Sciences, 6(6). Retrieved from: https://rjoas.com/issue-201206/i006_article_2012_02.pdf

NPC. (2020). Fifteenth Plan (2019/20-2023/24). National Planning Commission, Government of Nepal, Sighdurbar, Kathmandu, p.123.

Oladiebo, J.O., \& Fajuyigbe, A.A. (2007). Technical efficiency of women upland rice farmers in Osun state, Nigeria. Journal of human ecology, 22(2),93-100. DOI: https://doi.org/10.1080/09709274.2007.11906006

Regmi, H.R. (2017). Rice statistics in Nepal from 1951 to 2015 in Nepal. In: M.N. Paudel, D.R. Bhandari, M.P. Khanal, P. Acharya \$ K.H. Ghimire (Eds.).Rice Science and Technology in Nepal 2017. Crop Development Directorate (CDD) and Agronomy society of Nepal (ASoN), Lalitpur, Nepal,610-617.

Shrestha, J., Singh Kushwaha, U. K., Maharjan, B., Subedi, S. R., Kandel, M., Poudel, A. P., $\&$ Yadav, R. P. (2020a). Genotype $\times$ environment interaction and grain yield stability in Chinese hybrid rice. Ruhuna Journal of Science, 11(1), 47-58. DOI: http://doi.org/10.4038/rjs.v11i1.86

Shrestha, J., Kushwaha, U. K. S., Maharjan, B., Kandel, M., Gurung, S. B., Poudel, A. P., Karna, M. K. L., \& Acharya, R. (2020b). Grain Yield Stability of Rice Genotypes. Indonesian Journal of Agricultural Research,3(2), 116 - 126. https://doi.org/10.32734/injar.v3i2.3868

Uldare, A.O. (2014). Analysis of efficiency of mechanized and non-mechanized rice production in Kaduna state, Nigeria. Thesis submitted to the school of postgraduate studies, Ahmadu Bello University, Zaria in partial fulfillment of the requirements for the award of master of science degree in agricultural economics. Department of Agricultural Economics and Rural Sociology. Faculty of Agriculture, Ahmandu Bello University, Zaria, Nigeria, Pp.50-51.

Vortia, P., Nasrin, M., \& Bipasha, S.K. (2019). Extent of farm mechanization and technical efficiency of rice production in some selected areas of Bangladesh. Geo Journal (2019). DOI: https://doi.org/10.1007/s10708-019-10095-1. 